\title{
Reporting the Night of Broken Glass
}

\author{
The Swedish Press and the Final Rehearsal \\ Before the Holocaust
}

\author{
GÖRAN LETH
}

On the night between 9 and 10 November 1938, the Nazi regime staged a gigantic pogrom throughout Germany, Austria and Bohemia. The events have been entered into the records of history as the "Reichskristallnacht" or the Night of Broken Glass, a scornful euphemism coined by the perpetrators in reference to all the shattered glass of Jewish shops and homes. What passed that night and in the days to follow can be seen as a final rehearsal before the Holocaust. The violence, the large-scale arrests and deportations to camps and the subsequent massive economic and judicial assault laid the ground for the destruction of a people, even physically.

It must be of matter of greatest moment to investigate the newspaper coverage of the Nazi outrages. They were in fact preparations for an act of genocide. How did the world press react to what happened? This paper deals with mediation of the news of the Swedish newspapers, the press of a neutral country invested with a good deal of traditional sympathies for German culture. In particular, it highlights the reporting of one newspaper, Stockholms-Tidningen, using it as a paradigmatic example. The first conclusions of the scrutiny are that Swedish readers were provided with a mass of information. This entails an inquiry into how they were informed. The argument here is that Swedish journalism adjusted awkwardly to a new radical agenda of Nazi anti-Semitism.

The article that follows is a first draft text. The full investigation will include three successive stages, of which the first is a close reading of the reporting that appeared in Stockholms-Tidningen. In order to make a judgement about the material in this particular newspaper, it is reasonable to do a comparative study of the reporting of the Night of Broken Glass in other Swedish newspapers and in the international press, notably the English and American press. The second stage will comprise such a comparison. To reach a deeper understanding of the role of the press at the time and the significance of its reporting of events concerning the German Jewry, the analysis begs questions of the Nazi ideology and the character of the radicalisation of anti-Semitism. The third stage will incorporate into the analysis perspectives from the political history of Nazi Germany, of the history of the Holocaust, and the history of ideas of German culture.

The article below covers the first stage and gives some leads into the implications of the two following stages. 


\section{The Background}

Proclaimed pretext to the pogroms was the shooting of the Legation secretary in the German embassy in Paris, Ernst vom Rath, by the seventeen-year-old Polish Jew Herschel Grynszpan on 7 November. Grynszpan's action was provoked by the series of events that began with the decision of the Polish government to render stateless thousands of Poles living abroad, including some fifty thousand Polish Jews living in Germany, in March earlier that year. In October the German authorities rounded up seventeen thousand of these people and with great violence hustled them into a no-man's land between Germany and Poland, since the Polish government refused to admit them. Among the deportees were Grynszpan's parents and two sisters. Illegally residing in Paris, he got the news of the family's appalling situation through a letter from his sister and, fused with what he learnt from the press of the ever-deteriorating conditions of Jewish people in Germany, this produced a highly agitated state of mind. ${ }^{1}$ As vom Rath lay on his deathbed the Nazi propaganda machine went to work, portraying the act as an international Jewish conspiracy and orchestrating a campaign of vengeance in the newspaper press. ${ }^{2}$ In this atmosphere, several attacks on Jews and Jewish property were carried out in the following days. Vom Rath expired late in the afternoon 9 November and within hours pogroms were in progress throughout Germany, Austria and Bohemia.

The immediate results of the night of anti-Semitism turned loose were 267 destroyed synagogues and 7,500 vandalised businesses. Ninety-one Jews had been murdered and hundreds more had committed suicide or died later following mistreatment in the camps. Thirty thousand were incarcerated in camps. ${ }^{3}$

In reality, what happened in November was the culmination of a sinister development that had been going on the whole year. From April to October the authorities had issued a number of decrees directed against the Jewish population. ${ }^{4}$ Synagogues in Munich and Nuremberg had been torn down during the summer for the alleged reasons that they posed traffic problems and were at odds with the town character. ${ }^{5}$

The significance of the Night of Broken Glass was that it demonstrated for the first time that the Nazis looked for a violent solution to the 'Jewish Problem'. ${ }^{6}$

\section{Stockholms-Tidningen}

Stockholms-Tidningen is the natural choice for a number of reasons, when one wants a point of departure for an exploration of the Swedish press coverage of the Night of Broken Glass. At the time, this daily outdid all its competitors with a circulation of 400,000 copies a day. Despite the title, it was not only a Stockholm-spread newspaper but was also read throughout the country. Politically it defined itself as liberal, nevertheless in the course of the thirties it increasingly came out as a pro-German mouthpiece. Consequently, it catered to that big chunk of Swedish public opinion that nurtured a special kinship with Germany. That is not to say that the newspaper leaned towards a Nazi point of view, but rather why it makes a good case study as to how pro-German opinion reacted under Nazi pressure. Stockholms-Tidningen was also the paper that produced the most extensive coverage of the Night of Broken Glass among all the Swedish press. Quite a few competitors referred to its reports when stating the facts of the event. Furthermore, we happen to have some inside knowledge of Stockholms-Tidningen's particular correspondent to Germany at the time. And this knowledge can inform our understanding of the meaning of the reports. 
It is indeed a wealth of information that readers were offered in the course of the escalating assault on the German Jewry. People could know in detail what was going on, if they so chose. There were warnings beforehand of what was about to happen. And once the pogroms were put in motion their proportions and particulars were accounted for, as was the deep involvement of the regime.

The material appearing in Stockholms-Tidningen from 9 through 12 November 1938 will be presented in two steps. Step one will be a first impression account, providing an overview as well as an exposition of the most important bits of information relayed to the readers. Step two follows as some bewildering features loom into the foreground. It will be a second impression reading, focusing on a few critical aspects of the reports.

\section{First Reading}

Earlier research on the Swedish press and the Holocaust has concluded that there was a good amount of information available to the Swedish audience. ${ }^{7}$ This claim is confirmed when we take a closer look at the reporting of Stockholms-Tidningen. To start with, the paper gave warnings on 9 November that serious actions against the German Jewry were in the offing. The headlines that day signalled an ominous atmosphere in Germany: 'Reprisals against all Jews in Germany for the Paris shooting announced';8 'German plans to create ghettos in the cities. Intensified control of Jews. The press demands foreigners should also be targeted.' ${ }^{9}$ The state of the wounded diplomat was keenly observed: 'vom Rath in critical condition'. ${ }^{10}$

And, more specifically, the newspaper said: "Rather serious anti-Jewish manifestations have been staged in Hessen". "All German press betoken implacable consequences for the Jews residing within the realm', continued the report, and Hitler himself is said to have received the news of the shooting with such a sinister calm that it frightened those around him. Völkisher Beobachter stated clearly that after this deed, it was inconceivable that hundreds of thousands of Jews dominated whole shopping streets in German cities and towns. Leading party circles anticipated, it said, that the National Socialist regime would now move on without further ado with all measures deemed necessary to quicken a solution to the 'Jewish question in the country'. In Kassel, Jews had been fetched from their homes and pushed into a meadow, then led down to the basement of a brewery. Demonstrators forced themselves into the local Synagogue and caused damage. There was also information of cases of battery . As to the exact forms of reprisal, this was not yet clear, however until the Jews had been brought together in specially designated streets they were to report daily at the nearest police station. Furthermore, it was assumed that the right of Jews as for any citizen to move around the country would be invalidated, and befriending Jews would be much more harshly dealt with than had been the case before. ${ }^{12}$

The news of the pogroms had not yet reached the office 10 November; consequently the newspaper was still reporting from the build-up: 'The German diplomat in Paris dies of gunshot injuries. Increased resentment against the Jews in Germany. Synagogue set on fire, burnt down to the ground.'; 'The Dessau police had to protect Jews from demonstrators'. Stockholms-Tidningen told of several instances of anti-Semitic manifestations and particularly mentioned that the townspeople of Herafeld in Westphalia had stormed the synagogue and set it ablaze. ${ }^{13}$ What was described as 'resentment' had increased enormously, not only, the Berlin correspondent considered, among National Socialist youths and party organisations but also largely among ordinary Germans. And, remark- 
ably enough, he even stated: 'this night surely every Jewish premises would have been raided and every synagogue set on fire, had not the authorities, as they now actually do, kept their 80 million Germans in such tight rein. ${ }^{14}$

As we can see, readers of Stockholms-Tidningen should have been highly aware of what was going on in Germany in the wake of the Paris shooting. It was obvious that the Nazi regime would hold all German Jews responsible for the attack, and that it would respond with measures which violated their human rights. That German reactions had a distinct smell of physical violence, posing a threat to both Jewish property and life, can hardly have escaped anyone. Had there been any incitement whatsoever to raise a voice against an imminent calamity, here were every reason and argument. Given the known character of the regime as a dictatorship, readers should also have been put on guard by the aggressiveness of the German press, which the reports scrupulously relayed. Reasonably, there could have been no doubts about this being an orchestrated campaign, sanctioned from highest political level.

It was not before 11 November that Swedish readers were informed of what had passed during the night between the 9th and 10th in the Reich. The correspondent must have felt the urge to eat his own words, because the authorities were indeed far from keeping the Germans in tight rein, and precisely what he had predicted not to happen had in fact happened. The headlines spelled out the extent of the attacks and the havoc. 'Violent persecution of Jews in all Germany. Synagogues to ashes, stores wrecked. Hundreds of thousands of Jews arrested. Berlin's Jewish districts look as have been air-bombed. The mob looted demolished shops. Thursday blackest day of German Jewry.'; 'All synagogues in Berlin laid in ashes. This went too far, even anti-Semites thought'; 'Death-blow to Jewish business in Germany. Whole shopfronts ruined. Merchandise spread on the street.'; 'The Jews expelled from Munich.'

The reports went into detail of the events. A brutal revenge, they said, was taken on the Jews, when angry crowds, lead by 'storm troops', forayed synagogues and set them ablaze, destroyed and pillaged shops, as police and fire brigade were incapable of intervening..$^{15}$ Silverware, furs, furniture and various goods were strewn out into the business streets. In Berlin, one could witness how several Jews were badly beaten, and at Kurfürstendamm itself, the account pursued, a Jew was thrown out of a window from the second floor of a house and was thereafter pulled by the feet, heavily bleeding. A yelling crowd armed with sticks chased another Jew of about 60 years of age nearby the synagogue at Fasanenstrasse. He also suffered from profuse bleeding and was repeatedly lying down in the street unable to get up, under constant battering. A group of workers who tried to intervene against some plunderers were driven away by a squad of armed SA-men. ${ }^{16}$ The correspondent could also see for himself how the synagogues were left burning, with no attempts to put out the fires. 'The firemen stood and looked on'. ${ }^{17}$

It was clear from the reports that the actions implicated the authorities. The crowds attended to the orders of NSDAP-party men. ${ }^{18}$ The newspaper recorded how the vandalising of hundreds of high street shops took place without any sight of a policeman for the entire day. When a retired commanding officer tried to reach police command by telephone in order to put a halt to the rampage, the evidence was that they left his remonstrations unheeded. The conflagrations, which wasted Jewish sites of worship, were witnessed, Stockholms-Tidningen had to recount, by impassive firemen.

At last the German government, in the shape of propaganda minister Josef Goebbels, ventured to comment on what had taken place during the last few days. At a press conference in Berlin 11 November Goebbels expanded on the atrocities in front of the gathering of foreign correspondents. The headlines of Stockholms-Tidningen the following 
day read: 'No looting - not a Jew touched! Goebbels explains. New mass arrests, the feelings among Jews are not to be described'; 'Dr. Goebbels promises new Jew laws. Had to leave without the usual clapping'. The propaganda minister allowed no questions from the journalists, and it seems as though his words made Stockholms-Tidningen's man confused and sceptical but nevertheless all ears. Goebbels, he set forth, had undertaken to prove that the accounts of the foreign press, which were relatively concordant, had been incorrect on crucial points. The correspondent echoed Goebbels's views that the raids had not been organised, the police had been too few but not passive, the plunders had not been masterminded from above and not a hair on a Jew's head had been hurt. Dr. Goebbels denied all responsibility for what had occurred and described the events as a natural reaction of the people. And, one could not, the correspondent quoted him saying, 'allow the police to shoot at the people'. The report went on to say that in the course of Friday large numbers of Jews had been taken into custody. ${ }^{19}$

However, confronted with the manifest unconcern, Stockholms-Tidningen's man on the spot gave the impression of having been taken in by the National Socialist dignitary, subsequently seeing his task as none other than relating the Nazi story.

The account of the press conference provided an extraordinary image of Goebbels's appearence. Dr. Goebbels, it read, begged us, after we had represented yesterday's events from our point of view, to then allow space for his opinion. 'He stood', it went on, 'in the centre of the parquet floor in the Pompeian room, with two officials from the Ministry of Propaganda behind him, surrounded in a circle by the foreign correspondents. Naturally, all were utterly eager for what the little doctor should say, and one even admired him for his courage to, in this manner, make his appearance the very next day in the middle of the international press. ${ }^{20}$

Henceforth, the newspaper populated its columns with appalling statements. The subheads conveyed an insolent and frightening meaning. "II should have done it properly"'; 'Identical gauntlets consequently - no organisation'; 'The Jewish problem shall be resolved legally'. The propaganda minister said that if he had been behind the manifestations, one would have seen not hundreds and thousands on the streets but hundreds of thousands and millions. He would have done it much more successfully and radically. Furthermore, he objected to the charges of pillage, but added jocularly, if an old woman had found something that she thought would make a nice Christmas gift for her daughter, one must understand that. Likewise, he dismissed accusations of Jews in Munich being collected in the middle of the night and transferred to concentration camps only in their nightgowns. Again, he adjoined in jest, then the government itself would have been forced to supply the clothing - one could not keep prisoners in concentration camps for years without anything but a nightshirt.

After this performance, the Swedish journalist witnessed to his own frustration that when the Nazi chieftain had had his say, he turned his back on the international press corps and left. There were quite a few questions one would have wished to put to him, the journalist ruminated. As it was, one could only silently give him the space for his viewpoint that he had asked for. 'Never before has an explanation of Goebbels been so interesting. His appearance on the whole in such manner, likewise the content of his explanation both what he said and what he did not say and how he, with an appeal to the loyality of the foreign press, expressed it, conferred a cogent insight into the atmosphere behind the scenes at Wilhelmstrasse the day after.' ${ }^{21,22}$

Today, long afterwards, one might be inclined to perceive a note of irony in the journalist's writings. Nevertheless, this would be a mistake. He was, indeed, bewildered and unsatisfied, perhaps even perturbed, but his high opinion of the German minister of 
propaganda was real enough. Of course, these are assertions that need to be supported by facts and I will return to them later. But first, there is another question that demands an answer: How is one to accommodate the previous graphic illustrations of the horrible abuses of the German Jewry with the apparent deference to the representative of Nazi supremacy? Let us now reread Stockholms-Tidningen from 9 November onwards and be particularly observant as to how the newspaper packaged the reports.

\section{Second Reading}

On the first page of Stockholms-Tidningen of 9 November there is another headline that claims our attention. 'Bonnier kiosk causes protests. Tobacconists of the Nybro circus area oppose plans of an Alga kiosk: We have received the announcement with dismay.' The item went on to say that the projected building of an annex, where air travellers would be catered to with newspapers, tobacco and sundry had stirred up quite a commotion among the shopkeepers in the vicinity of the Nybro circus. The newspaper's wording was rather conspicuous: 'At once, the Bonnier group pushed ahead and tried under the sign of the Swedish Press bureau to lay hands on the lucrative business.' 23

The Bonniers are one of Sweden's most known Swedish-Jewish families. Traditionally, they have been linked to the book and newspaper publishing business, and their flagship was (and is) one of the major dailies and perhaps the first competitor of Stockholms-Tidningen, Dagens Nyheter. The influence of the Bonnier family in the publishing industry became a heated topic of discussion during the thirties. Nazis and proGerman circles continuously launched verbal attacks on their so-called unseasonable and foreign domination of the newspaper market. The owner of Stockholms-Tidningen even tried to buy out the Bonniers' interest in Dagens Nyheter. Even among Dagens Nyheter's own staff, not least its management, the owner family was seen as an uncomfortable fact during these years, and one would have preferred to put an end to the relationship. As a consequence, the family's influence on the policy of its own paper diminished rapidly in the course of the pre-war events. ${ }^{24}$

Accordingly, the item about the Bonnier kiosk was far from being a piece of neutral and routine news reporting. It had a plain anti-Semitic message, and the phrasing was fully deliberated: 'the Bonnier group pushed ahead ... to lay hands on the lucrative business.' The greedy Jew was, of course, a stock character of anti-Semitic propaganda.

Inside that same day's newspaper one finds another item of similar tendency. The story was about a company manager who stood trial for purveying Austrian Jewesses with Swedish passports in order to give them a helping hand in leaving Austria. Now, this could have been a 'Schindler's List' narrative, an unexpected but nonetheless brave saving angel effort. However, the framing Stockholms-Tidningen bestowed on it was quite the opposite. The headline read: "Sven Bylund planned to "save" Jew capital out of Austria. Export of Jewesses with their money. - Busted swindler at the bar.' The body text followed up telling about Jewish women in Vienna, 'who were hankering after Swedish citizenship' and of 'the profitable trade' of helping Jewesses and conveying hard cash out of the country. ${ }^{25}$

It is this context we must bear in mind as we proceed to reread the reports of the Night of Broken Glass.

As early as the news reports of the legation secretary's critical state of health, there was a peculiar slant to the representation of the German situation. The attack, as the reporter put it, had made 'a great impact' in Germany, and all over Berlin people nurtured 
the view that one would not 'for all the gold in the world' wish to be a Jew within the borders of the Third Reich. ${ }^{26}$ The description gives the impression of an understanding for the aggressive reactions. The phrase 'for all the gold in the world' was in its everyday parlance derogatory of the terror felt by the Jewish population before the inflammatory words of German newspaper headlines and political leaders. Moreover, the phrase, hardly by coincidence, carried the same old spiteful allusion to the greediness of Jews.

When reporting the actions against Jews prior to the events of the night between 9 and 10 November, the text referred to information of physical assaults and added 'which would be quite understandable due to the influence of the Paris attack' ${ }^{27}$ Despite the obvious fact that professional journalism called for a hearing of Jewish witnesses to the dramatic and frightening development, the correspondent never bothered to do so. Throughout the reports that followed the next few days, Jews never had their say. What is more, they do not even appear as individuals. When mentioned, they are nameless, faceless and, as stated, speechless, all blending into one indistinguishable mass.

If being someone is what first and foremost defines a human being, this strain of Stockholms-Tidningen's coverage is particularly consequential and ominous. By contrast, the correspondent gives evidence early on to his self-assured capability to discern Jews from other people: 'Today in Berlin there is not one single Jew to be seen out in the streets'. The alleged observation bespeaks a presumed racial awareness.

A more myopic reading of the headlines of the following day, when the nationwide pogroms were still not known, also reveals the sympathetic attitude towards the German reactions and the detached frame of mind concerning the Jewish population. 'Increased resentment against the Jews in Germany.' 'The Dessau police had to protect Jews from demonstrators'. The expression 'resentment' shows the newspaper preferred to see what happened from the point of view of the aggressors, whereas Jewish people consistently featured as abstract nouns. And now, in the clarified context, the remarkably unwitting prophetic utterance - 'this night surely every Jewish premises would have been raided and every synagogue set on fire, had not the authorities, as they now actually do, kept their 80 million Germans in such tight rein' - takes on new meaning. ${ }^{28}$ It betrays the correspondent's trust in the regime, but also his readiness to normalise atrocities. At that, it puts on display his lack of preparedness and unwillingness to see what a Nazi sway in Germany held in store.

Thus, when we once again take a look at the reports of the pogroms, we will detect an undertext.

'Jew persecution'; ${ }^{29}$ 'the Jew action'; 30 'Jew thrown out of window';31 'the fleeing were apparently Jews [the italics are mine]';32 'the Jews expelled';3 'a large number of Jews'; ${ }^{4}$ 'Strikes a Jew or shoots a Jew'; ${ }^{35}$ 'the Jew shops'; 36 'male Jews'; 37 'Jew laws'; 'the Jewish problem [verbatim 'the Jew problem']'; 39 'the Jewish question [verbatim 'the Jew question]'. ${ }^{40}$ The expressions 'the Jewish problem' and 'the Jewish question' are particularly worth noting in this series of dehumanising concepts and descriptions.

Those conceptions were pivotal to the Nazi anti-Semitism; its constant radicalisation turned around them. Once, there were a 'problem' and a 'question' that needed a solution and an answer. And the National Socialists were ever more aggressively eager to set that balance right again. The expressions were incorporated into Swedish, and indeed into European, political discourse even before Hitler's assumption of power in Germany. As early as 1932 the expression 'the Jew problem' appeared, strangely enough, in the literary monthly of Bonnier's publishing house, Bonniers Litterära Magasin. ${ }^{41}$ It did not 
meet with any kind of riposte in the remainder of the issue. In Stockholms-Tidningen's reporting the expressions occurred without quotation marks, having become commonplace when speaking of contemporary Europe, and integral parts of Swedish news language.

It is not surprising, then, that we find that Stockholms-Tidningen's correspondent had absorbed other significant words and phrases from the Nazi vocabulary into his own accounts. Quite a few 'Aryan shops' had been rampaged by mistake in Munich, ${ }^{42}$ and Jewish shop owners were not allowed to sell off the premises and stocks to 'Aryans', he set forth. ${ }^{43}$ He related the arrests of tens of thousands of Jews as them having been taken into 'protective custody'. ${ }^{44}$ Confronted with the gruesome look of the pogroms, he resorted to what he saw as a more dignified Germany and referred to 'genuine German antiSemites'. ${ }^{45}$ As if there were a kind of honest anti-Semitism, which, by all means, should be welcomed. And those, he offered, thought the pogroms went too far - a proposition that must have left the readers in suspense as to what would not have been too far. ${ }^{46}$

Taking into account what is detailed above, it must not have been a big step in crossing the line to normalise the outrages. And the correspondent certainly did this. At the scene of the havoc, he informed the readers that he wanted to allow the National Socialists their say. Since he never gave anyone of the Jewish population their say, this was indeed a strange kind of justice. In any event, the question he put to a reported well-known party representative was the following: 'Have not those Jews, whom you from the beginning and in reality want to get at, left long ago, and are not the innocent the ones staying behind to suffer?' ${ }^{47}$ This was truly a plain subscription to far-reaching anti-Semitism. Despite his qualifications, the journalist obviously thought it reasonable to 'get at' Jewish people.

He provided impressions of events seemingly unfolding in an everyday manner, where the threats were posed to bystanders rather than to the actual victims. 'Huge masses of people were out to look at the spectacle, among them an impressive number of women with their toddlers in prams - as always during quasi-revolution riots. Since they, for want of maids, had to bring the children along into an often highly dangerous throng in order to not miss out on the free show.' 48 The wording - e.g. 'free show' - is, when one considers what is dealt with, abhorring.

The cynicism, which often marked the whole course of events, was simply passed on by the correspondent, apparently without feeling a moment's urge to reflect and react against it. 'In a number of cases large department stores have been set on fire ... but that was out of the border of the planned action and in such cases the Jewish proprietors have been arrested on suspicion of arson.' ${ }^{4}$ 'A bunch of arrested Jews have been equipped with tools and sent off to the destroyed synagogues to clear up at the scenes of the fires. ${ }^{50}$

Even the chief officer of the fire brigade had, by the look of it, found it fit to mock the feelings of the afflicted in person. He paid a visit to the scene of the burning synagogue at Fasanenstrasse in Berlin with the intention 'to - what the people outside made jokes about - investigate whether the fire also had been set with proper expert knowledge. ${ }^{51}$ Notwithstanding, we may suspect his repudiation here, the absence of any critical comment from the journalist to this perversion of authority, only added to the scorn towards the victims.

The second reading gives us a different conception of Stockholms-Tidningen's accounts of the Night of Broken Glass. Still, from what is said thus far we must not jump to the conclusion that the journalist was simply a crypto-Nazi, trying whatever he could 
to sell the brutal message of his principals. He was indeed shocked at what he saw, and did voice criticism of the unbridled violence. If, today, we are to fully understand his reports a more subtle interpretation is called for.

$$
* * *
$$

I shall end by just suggesting some of the forthcoming investigations.

In other Swedish newspapers the German perspective was not this manifest. Their coverage was, however, more limited than that of Stockholms-Tidningen, and it seems as though they actually played down the events. Dagens Nyheter, for example, did not top with the news before 12 November, although it was well known by 11 November. The framing of the news was often extraordinary, the victims were never in focus, and Svenska Dagbladet, for example, worried in their headlines primarily about the devastated insurance values. Their concern was the insurance companies, not the Jewish proprietors. Most importantly, as in Stockholms-Tidningen, nowhere in the reporting is a Jewish individual to be found. Likewise here, Jews formed a collective without features. In leading articles the newspapers aired protests, but again, the issue was not the threat to the German and European Jewry, but that to German culture. Besides, the conviction was that the events were not representative of Germany. Nowhere is there a call for action, and the absence of any governmental comments or protestations from the Swedish elite is most striking to a reader today. The underlying notion seems to have been that, overall, this was an internal German affair. The great exception was, not surprisingly to anyone with some knowledge of Swedish press history, Göteborgs Handels- och Sjöfartstidning. Its coverage was highly prioritised, the headlines were outspoken, and the tragedies of individual Jews were told.

Both British and American coverage were pungent. In relation to the majority of the Swedish press, it is noteworthy that the Manchester Guardian, for example, visited the ousted Jewish families in the no-man's-land between Germany and Poland before the Night of Broken Glass and gave a vivid picture of their tragedy. Times and Guardian also offered resistance to the new Nazi manner of understanding the world. Expressions like 'Aryans' and 'protective custody' were put in quotation marks. What is most conspicuous in the Anglo-Saxon press is the weight it accorded to pronouncements of condemnation from politicians and other public persons.

The journalist Christer Jäderlund was of German parentage on his mother's side. He had an exceptional, favoured position among the foreign press corps in Berlin. Notwithstanding, he was expelled twice from Germany as the regime did not always relish his writings. In spring 1941 there appeared in Sweden a pamphlet calling for Germany's victory in the war, entitled The Struggling Germany. One of the contributors was Jäderlund. Obviously, he had experienced what he had reported from the Night of Broken Glass. Afterwards he had been witness to, no doubt, many more and worse things. Despite all this, he thought only a German victory would ensure a happy outcome of the war. In other words, we are confronted with the enigma of his sympathies. If, only for a moment, we could think of Jäderlund as his own reader, it is clear that it was quite possible to register all the horrors that hit the Jews and yet follow close behind Nazi Germany. To understand why, we need to look far beyond the reporting's face value.

A more penetrating analysis enquires about the contemporary meaning of StockholmsTidningen's account of the Night of Broken Glass. The motive for such an enquiry is naturally a desire to place journalism into a larger historical context. How could 
Stockholms-Tidningen have influenced the Swedish opinion at the time? Implicitly, here lies the wider-scope question: How could European press coverage of the Night of Broken Glass have influenced European opinion?

'How was it possible?' 'Why did anyone not act?' These questions relating to the Holocaust troubled the post-war world. The standard replies were: 'We did not know.' Now, the survey above makes it quite clear that there was plenty of information available at an early stage. The indications are that, henceforth as well, information was rich. If one wanted to know, one could have known. This leads me to propose quite a dramatic counter-hypothesis: That 'we' knew very well. And this is precisely why the Holocaust was possible.

Could such a hypothesis really have any credence? The question informs an enquiry for the meaning of the reporting. But before going about this, we must ponder the character of National Socialism. The premise here is that it was a revolutionary movement. Contemporaries spoke of Hitler's taking power as the 'German Revolution'. Recent research into the history of Nazi Germany has also called attention to the revolutionary aspect. ${ }^{52}$ I find my inspiration in this research, but also in works by two other scholars. Saul Friedländer introduced the term 'redemptive anti-Semitism' in his book Nazi Germany and the Jews. The Years of Persecution, 1933-1939. By this he meant a belief that Germanhood and the Aryan race were to perish if the struggle against the Jews was not joined. Thus, redemption would come as liberation from the Jews. The philosopher Isaiah Berlin has elaborated on 'The Apotheosis of the Romantic Will' in German culture (to be found in his book The Crooked Timber of Humanity. Chapters in the History of Ideas). This 'will' he characterised as a determination to live one's own life, to form one's own values, to sing one's own songs, to be ruled by one's own laws, not to be assimilated to forms of life that belong to all - a quest for self-realisation not to be impinged upon by alien obstacles. I assume, then, that Friedländer's term 'redemptive antiSemitism' makes anti-Semitism absolutely central to National Socialist ideology: a revolution should annihilate the Jews. The will, again, is consequently the fervour of that revolution.

From these assumptions I go on to propose that the Nazis stood before a huge undertaking to spark revolutionary enthusiasm within the German people, a people defeated in World War I and totally disillusioned by the recessions of the twenties. For this purpose they invented a strategic formula, which I call 'inversion of values'. The Nazis turned black to white and white to black. What I finally set out to do is to show how this inversion of values is relayed and enacted in the reports of Stockholms-Tidningen.

\section{Summary}

The article highlights the reporting of the Night of Broken Glass in the Swedish daily Stockholms-Tidningen from 9 to 12 November 1938. The choice of StockholmsTidningen as a research object is a natural one: at the time, this newspaper had the largest circulation among the Swedish press. Since the Night of Broken Glass was crucial to the unfolding of the Holocaust, to study the press coverage of the event must be highly important. The inquiry is conducted in the form of two readings: a first impression reading providing an overview as well as an exposition of the most important bits of information, and another more analytical reading, focusing on a few critical aspects of the reports. The two readings represent the first of three planned levels of investigation. 
The conclusions of the first reading are that the readers were provided with a wealth of information of the escalating assault on the German Jewry. It was possible to know in detail what was going on. The reporting gave beforehand warnings, the following pogroms were duly represented as to proportions and particulars, and the regime's guilt was made clear. The conclusions of the second reading are that, side by side with the reports from Germany, other items with clear anti-Semitic bias appeared in Stockholms-Tidning. Jäderlund's reports are, despite his professed disapproval of the instances of violence, saturated with Nazi vocabulary: 'Aryan', 'non-Aryan', 'the Jewish problem', 'antiSemitism', 'protective custody', and words like 'Jews' and 'Jewish' are endowed with new dehumanising meanings. And most consequential is the fact that the reporting, time and again, normalised the persecutions and atrocities.

The preliminary results give good reason for further investigations, the course of which the article provides only a few suggestions for. Comparative studies of other Swedish, British and American newspapers may on the one hand corroborate, with one or two exceptions, the Swedish paradigm set by Stockholms-Tidningen, and on the other hand show the critical perspectives, all things considered, available to the international press. To understand the role of the press in Sweden's response to the Holocaust, one must look for the essence of the radicalisation of Nazi anti-Semitism. The journalism may be seen as both reflecting and interplaying with a constantly renewed anti-Jewish agenda.

\section{Notes}

1. Michael Burleigh, The Third Reich. (New York: Hill and Wang 2000) pp. 323-4.

2. Burleigh op.cit. pp. 324-5.

3. Saul Friedländer, Nazi Germany and the Jews. Vol. 1 The Years of Persecution, 1939-1939. (New York: HarperCollins 1997) p. 276.

4. Heinz Lauber (ed.), Die nacht in der im Deutschen Reich die Synagogen brannten. (1988) p. 33.

5. Burleigh op.cit. p. 329.

6. Abraham J. Edelheit \& Hershel Edelheit, History of the Holocaust. A Handbook and Dictionary. (Boulder: Westview Press 1994) p. 49.

7. Steven Koblik: "Om vi teg, skulle stenarna ropa": Sverige och judeproblemet 1933-1945. (Stockholm 1987); Paul Levine: "The Swedish Press and the Holocaust". Opubl. masters-avh. (1987); Svanberg \& Tydén: Sverige och Förintelsen. Debatt och dokument om Europas judar 1933-1945. (Stockholm 1997); Paul Levine: From Indifference to Activism. Swedish Diplomacy and the Holocaust 193844.(Uppsala 1998)

8. Repressalier bebådas mot alla judar i Tyskland för Parisdådet. Stockholms-Tidningen 9 November 1938.

9. Tyska planer på att skapa ghettokvarter i städerna. Skärpt kontroll över judarna. Även utlänningar skola drabbas kräver pressen. Stockholms-Tidningen 9 November 1938.

10. von [sic] Raths tillstånd mycket allvarligt. Stockholms-Tidningen 9 November 1938.

11. "I Hessen ha ganska allvarliga antijudiska demonstrationer förekommit." Repressalier bebådas mot alla judar i Tyskland för Parisdådet. Stockholms-Tidningen 9 November 1938.

12. Tyska planer på att skapa ghettokvarter i städerna. Skärpt kontroll över judarna. Även utlänningar skola drabbas kräver pressen. Stockholms-Tidningen 9 November 1938.

13. Tyske Parisdiplomat död av skottskadorna. Förbittringen mot judarna ökad i Tyskland. Synagoga satt ibrand, nedbrann till grunden. Stockholms-Tidningen 10 november 1938.

14. Dessaupolisen måste skydda judarna för demonstranter. Stockholms-Tidningen 10 november 1938.

15. Våldsam Judeförföljelse i hela Tyskland. Synagogerna i aska. Affärerna förstörda. Hundratusentals judar arresterade. Berlins judiska affärskvarter se ut som om de luftbombarderats - Pöbeln plundrade de demolerade butikerna - Torsdagen de tyska judarnas svartaste dag. Stockholms-Tidningen 11 November 1938.

16. Dödsstöt åt judarnas affärsliv i Tyskland. Hela butiksfasader förstörda. Butikernas innehåll på gatan. Stockholms-Tidningen 11 November 1938. 
17. Gatuslöddret ekiperade sig. Stockholms-Tidningen 11 November 1938.

18. Dödsstöt åt judarnas affärsliv i Tyskland. Hela butiksfasader förstörda. Butikernas innehåll på gatan. Stockholms-Tidningen 11 November 1938.

19. Inga plundringar - Ingen jude rörd! Goebbels förklarar. Nya masshäktningar, stämningen bland judar obeskrivlig. Stockholms-Tidningen 12 November 1938.

20. Dr Goebbels utlovar nya judelagar. Fick gå utan sedvanlig applåd. Stockholms-Tidningen 12 November 1938.

21. Dr Goebbels utlovar nya judelagar. Fick gå utan sedvanlig applåd. Stockholms-Tidningen 12 November 1938.

22. Dr Goebbels utlovar nya judelagar. Fick gå utan sedvanlig applåd. Stockholms-Tidningen 12 November 1938.

23. Bonnier-kiosk vållar protest. Nybroplanstraktens tobakshandlare opponerar sig mot planerad Alga-kiosk: Med bestörtnng ha vi mottagit underrättelsen. Stockholms-Tidningen 9 November 1938.

24. Jarl Torback, Dagens Nyheter och demokratins kris. (Stockholm 1972) pp. ??.

25. Sven Bylund skulle "rädda" judekapitalet ur Österrike. Export av judinnor med deras pengar. Konkursbedragaren inför rätta. Stockholms-Tidningen 9 November 1938.

26. Tyska planer på att skapa ghettokvarter i städerna. Skärpt kontroll över judarna. Även utlänningar skola drabbas kräver pressen. Stockholms-Tidningen 9 November 1938.

27. Op.cit.

28. Dessaupolisen måste skydda judarna för demonstranter. Stockholms-Tidningen 10 november 1938.

29. Våldsam Judeförföljelse i hela Tyskland. Synagogerna i aska. Affärerna förstörda. Hundratusentals judar arresterade. Berlins judiska affärskvarter se ut som om de luftbombarderats - Pöbeln plundrade de demolerade butikerna - Torsdagen de tyska judarnas svartaste dag. Stockholms-Tidningen 11 November 1938 .

30. Alla Berlins synagogor lades i aska. Detta gick nu för långt tyckte även antisemiter. Stockholms-Tidningen 11 November 1938.

31. Dödsstöt åt judarnas affärsliv i Tyskland. Hela butiksfasader förstörda. Butikernas innehåll på gatan. Stockholms-Tidningen 11 November 1938.

32. Op.cit.

33. Judarna utdrivna ur München. Stockholms-Tidningen 11 November 1938.

34. Op. cit.

35. Judarna berövas nödvärnsrätten. Stockholms-Tidningen 11 November 1938.

36. Judebutikerna brinna i München. Stockholms-Tidningen 11 November 1938.

37. Brandbomber mot synagogorna i Wien. Stockholms-Tidningen 11 November 1938.

38. Dr Goebbels utlovar nya judelagar. Fick gå utan sedvanlig applåd. Stockholms-Tidningen 12 November 1938.

39. Inga plundringar - Ingen jude rörd! Goebbels förklarar. Nya masshäktningar, stämningen bland judar obeskrivlig. Stockholms-Tidningen 12 November 1938; Dr Goebbels utlovar nya judelagar. Fick gå utan sedvanlig applåd. Stockholms-Tidningen 12 November 1938.

40. Dr Goebbels utlovar nya judelagar. Fick gå utan sedvanlig applåd. Stockholms-Tidningen 12 November 1938 passim.

41. BLM 1932.

42. Brandbomber mot synagogorna i München. Stockholms-Tidningen 11 November 1938.

43. Dr Goebbels utlovar nya judelagar. Fick gå utan sedvanlig applåd. Stockholms-Tidningen 12 November 1938.

44. Dödsstöt åt judarnas affärsliv i Tyskland. Hela butiksfasader förstörda. Butikernas innehåll på gatan. Stockholms-Tidningen 11 November 1938.

45. Alla Berlins synagogor lades i aska. Detta gick nu för långt tyckte även antisemiter. Stockholms-Tidningen 11 November 1938.

46. Op.cit.

47. Op. cit.

48. Dödsstöt åt judarnas affärsliv i Tyskland. Hela butiksfasader förstörda. Butikernas innehåll på gatan. Stockholms-Tidningen 11 November 1938.

49. Dödsstöt åt judarnas affärsliv i Tyskland. Hela butiksfasader förstörda. Butikernas innehåll på gatan. Stockholms-Tidningen 11 November 1938.

50. Brandbomber mot synagogorna i Wien. Stockholms-Tidningen 11 November 1938.

51. Gatuslöddret ekiperade sig. Stockholms-Tidningen 11 November 1938. 
52. E.g.: Pierre Ayçoberry, The social history of the Third Reich, 1933-1945., George Mosse, The Fascist Revolution. Toward a general theory of Fascism., Martyn Housden, Hitler. Study of a Revolutionary?, Ian Kershaw, The 'Hitler Myth'. Image and reality in the Third Reich., Ian Kershaw \& Moshe Lewin, Stalinism and Nazism. Dictatorships in Comparison., Michael Burleigh, The Third Reich. 